\title{
FRAMEWORK FOR EVALUATING THE RELATIONSHIP BETWEEN THE OMNICHANNEL ONLINE SALES APPROACH AND PERFORMANCE OUTCOME IN THE CASE OF NICHE PRODUCTS
}

\author{
Viktorija Urbaitytè ${ }^{1}$, Aurelija Ulbinaité ${ }^{2}$ \\ Business Department, Faculty of Economics and Business Administration, Vilnius University, \\ Sauletekio al. 9, 10222, Vilnius, Lithuania \\ E-mails: 'viktorija.urbaityte@evaf.stud.vu.lt; ${ }^{2}$ aurelija.ulbinaite@ef.vu.lt (corresponding author)
}

Received 29 March 2020; accepted 06 May 2020

\begin{abstract}
Transformation from electronic commerce business model to social commerce business model empowered manufacturers of niche products to start retail businesses which are operating solely online. The selection of an online sales approach is a part of the online sales process which determines how end customers will be reached. Moreover, the online sales approach determines performance outcome, hence, this selection should be done after meticulous evaluation. This research, after a systematic comparative analysis of the academic literature, explores the omnichannel online sales approach and its relationship with performance outcome in the case of niche products and proposes a theoretical framework for the evaluation of this relationship. The theoretical framework includes financial and qualitative (customer satisfaction and customer loyalty) criteria which allow to evaluate performance outcome created by the omnichannel online sales approach in a holistic way. The performance outcome evaluation results can be used in the decision-making process when deciding whether the chosen omnichannel online sales approach meets the expectations of a business and its customers.
\end{abstract}

Keywords: omnichannel online sales approach, performance outcome, financial criteria, customer satisfaction, customer loyalty, niche product.

JEL Classification: L26, L29, L25.

\section{Introduction}

The advent of online retailing and ongoing digitalization has dramatically changed retail business models (Verhoef et al., 2015). Electronic commerce (e-commerce) activities such as purchase, sales, marketing and distribution processes of products and services are heavily affected by omnipresent social networks (Kim, 2013; Pentina et al., 2013; Baghdadi, 2016; Fotiadis \& Stylos, 2017) and social media (Andzulis et al., 2012; Huang \& Benyoucef, 2013; Huang et al., 2016; Bocconcelli et al., 2017; Tajvidi et al., 2018). Social networks and social media enabled customers to create user-generated content (online product reviews and recommendations), which has revolutionised traditional e-commerce into social commerce where social features are incorporated into online shopping (Hajli et al., 2017). The rapid development of social media and Web 2.0 has provided a huge potential to transform e-commerce from a product oriented environment to a social and customer centred one (Wigand et al., 2008).

The selection of sales approach is a crucial aspect of sales process. Sales approach directly affects performance results so the way how to reach customers has to be precisely chosen. Pure online players - companies functioning solely online - can choose different online sales approaches or use combined option called omnichannel approach. The choice of how to reach customers in online market can be explained as online sales channel which integrates seller's sale and buyer's purchase processes. This research is focused on a part of online sales process which is described by online sales approach and limited to pure online players who are providing niche products. Hence, this aspect helps to simplify online sales process because attention to other parts of sales process is not in the scope.

The gap in the academic literature is found because online sales approach is investigated as a part of brick-and-clicks business model (Song \& Zahedi, 2005; Kaplan \& Haenlein, 2010; Song et al., 2012; Hansen \& Sia, 2015; Parvinen et al., 2015; Verhoef et al., 2015; Viio \& Grönroos, 2016; Lapoule \& Colla, 2016; Chandna \& Salimath, 2018; Wait, 2019; Kim \& Takashima, 2019; Saleem et al., 2019) but not as only and in- 
dependent approach of sales process. After systematic comparative analysis of the latest academic literature we seek to fill this gap by investigating the integration of three different online sales channels (single brand web shop, online selling platform, social media sales) to omnichannel online sales approach and by making the evaluation of the relationship between this approach and its performance outcome. This integration is measured by financial and qualitative (customer satisfaction and customer loyalty) criteria. The main goal of this research is to propose the framework for evaluating the relationship between omnichannel online sales approach and performance outcome in the case of niche products.

\section{Theoretical background}

\subsection{The concept of online sales approach}

Online sales process guides the seller during relationship initiation with the buyer (Viio \& Grönroos, 2014). Selected online sales approach describes how customer will be reached. The lack of extended and fully described concept of online sales approach creates misunderstandings and does not let to fully examine online business. Various authors provide their standpoints about online sales approach. Table 1 shows leading and recognized concepts connected with online sales approach. Some of them are being used interchangeably which creates even more confusion. Different standpoints show that authors see online sales from various perspectives with different conceptual elements. This shows that an important part of learning the sales process is the understanding of the complexity involved in implementing or completing the process (Rippé, 2015).

A new created concept of online sales based on the insights from Table 1 describes online sales as mechanic e-saleswork together with digital interaction which uses knowledge of customer's preferences prior, during and after the sale alongside different selling channels to reach customer and co-create value together while completing sales process on the internet.

\subsection{Single brand online shop}

Unlike the traditional brick-and-mortar retail stores, an e-commerce business model is simply an online retail channel where a customer can order a product or a number of products from a merchant via a web-based portal that is identified as an ecommerce website or simply an online store (Saleem et al., 2019). Websites have become a highly valuable channel for retailers, one that enables them to sell products and services to customers, as well as to interact and communicate with those customers during each phase of the sales process (Song \& Zahedi, 2005) also prior and after the sale (Gerrikagoitia et al., 2015).

Table 1. Standpoints connected to online sales approach (source: created by authors)

\begin{tabular}{|l|l|l|}
\hline \multicolumn{1}{|c|}{ Concept } & \multicolumn{1}{|c|}{ Conceptual elements } & \multicolumn{1}{|c|}{ Source } \\
\hline E-selling & $\begin{array}{l}\text { Human interactivity, intentionality, persuasion, value creation } \\
\text { and closing }\end{array}$ & Parvinen et al., 2015 \\
\hline E-saleswork & Mechanistic process, automatization in value chain & Parvinen et al., 2015 \\
\hline Online selling & $\begin{array}{l}\text { Sales force automatization, sales-based customer relationship } \\
\text { management, online social network, mobile technologies, } \\
\text { companies' own websites }\end{array}$ & Ferrell et al., 2010 \\
\hline Online selling & $\begin{array}{l}\text { Reducing search costs; granting easy access to product and } \\
\text { price information; facilitating product comparisons; offering } \\
\text { greater accessibility, convenience and time-saving; involves } \\
\text { no travel, product carrying or restrictions on shopping hours }\end{array}$ & Wait, 2019 \\
\hline E-sales & $\begin{array}{l}\text { Advanced processes, enhanced efficiency, external relations } \\
\text { with clients }\end{array}$ & Falk \& Hagsten, 2015 \\
\hline Internet sales & High customer expectations & Jelassi \& Leenen, 2003 \\
\hline $\begin{array}{l}\text { E-commerce } \\
\text { based selling }\end{array}$ & $\begin{array}{l}\text { Knowledge of customer's preferences, prior the sale, during } \\
\text { the sale, after the sale }\end{array}$ & Gerrikagoitia et al., 2015 \\
\hline Sales process & $\begin{array}{l}\text { Documented method, repeatable method, similar to production } \\
\text { process }\end{array}$ & $\begin{array}{l}\text { Cooper \& Budd, 2007; Viio \& } \\
\text { Grönroos, 2014; Bernard et al., } \\
\text { 2016; Viio \& Grönroos, 2016 }\end{array}$ \\
\hline $\begin{array}{l}\text { Selling } \\
\text { process }\end{array}$ & Smaller part of sales process & Viio \& Grönroos, 2014 \\
\hline Online sales & Different functions & Parisot et al., 2014 \\
\hline
\end{tabular}




\subsection{Peer-to-peer online selling platform}

Peer-to-peer (P2P) websites have facilitated virtual entrepreneurship through their hardware and software improvements and new applications in connectivity technologies (Mačiulienė \& Skaržauskiené, 2016). P2P websites act as two-sided platforms connecting two different parties and charging one or more of them a fee for this facilitation (Chandna \& Salimath, 2018). Two-sided platforms create a specific service for online seller and online buyer who are seeking for each other which helps to gain various benefits. For example, these platforms have the chance to create many data streams that are opening many opportunities for further development (Sriram et al., 2015). Niche business owners are able to use P2P networks to leverage their businesses in ways that were not previously possible (Chandna \& Salimath, 2018). These platforms offer the opportunity for social relations, new modes of production and allocation, a scalable technological infrastructure, and an economy rooted in fairness and sustainability.

\subsection{Social media sales}

Social media refers to internet based applications built on Web 2.0, while Web 2.0 refers to a concept as well as a platform for harnessing collective intelligence (Kaplan \& Haenlein, 2010). The use of social media brought the shift in power from firms to customers (Berthon et al., 2012). The availability of various social media tools and functionalities may enrich communication between participants and provide a more interactive, social and collaborative user experience (Huang et al., 2016). Social media has given consumers much more control, information and power over the market process, presenting important challenges to retailers (Constantinides et al., 2009). As e-commerce continues to evolve into a distinctly more social activity (Yadav et al., 2013), customer is affected by intense influence of social media.

\subsection{Omnichannel}

We live in a customer-driven world, where the informed customer, not the retailer, dictates much of the desired content (Mosquera et al., 2017). Most distinctive aspects of omnichannel customer are shown in Table 2.

Omnichannel retailing refers to retailing that involves a synergetic integration of channels for the purpose of creating a unified brand experience for customers, regardless of the channel or stage they are in during the purchasing process (Cummins et al., 2016). This unified customer ex- perience is not linked to, or dependent on, any one channel, but related to a holistic brand experience (Hansen \& Sia, 2015). Omnichannel retailing makes a concept of integration of all digital channels business is proving. This process is managed by channel management and can vary from complete separation of channels to total integration. Customers consider sales and marketing channels as a single entity, and the shopping experience is experienced without interruption regardless of the type of channel used (Herhausen et al., 2015).

Nowadays, customers shop across channels (Lee et al., 2019), use many or all of the available sales channels simultaneously during the purchase process (Aiolfi \& Sabbadin, 2019) and sellers have turned into omnichannel retailing to remain competitive. In many cases terms multichannel and omnichannel are considered as identical ones. However, the literature considers omnichannel retailing as a new paradigm (Bell et al., 2014; Herhausen et al., 2015; Huré et al., 2017; Aiolfi \& Sabbadin, 2019; Lee et al., 2019). It is considered as the set of activities involved in the sale of goods or services through all the channels activated at the same time with complete interaction by customers and a full integration controlled by the retailer (Beck \& Rygl, 2015). Aiolfi and Sabbadin (2019) specify new omnichannel strategies as directed towards a more intelligent, integrated and creative use of technologies.

Table 2. Insights about omnichannel customer (source: created by authors)

\begin{tabular}{|l|l|}
\hline \multicolumn{1}{|c|}{$\begin{array}{c}\text { Insights about omnichannel } \\
\text { customer }\end{array}$} & \multicolumn{1}{c|}{ Authors } \\
\hline $\begin{array}{l}\text { Heavily influenced by } \\
\text { technology }\end{array}$ & Cook, 2014 \\
\hline $\begin{array}{l}\text { Requires active interacting with } \\
\text { the company, more demanding }\end{array}$ & $\begin{array}{l}\text { Mathwick et al., } \\
2002 ; \text { Cook, } \\
2014\end{array}$ \\
\hline $\begin{array}{l}\text { Highly connected by interest } \\
\text { rather than demographics }\end{array}$ & Cook, 2014 \\
\hline $\begin{array}{l}\text { Tend to spend more money } \\
\text { Kumar \& } \\
\text { Venkatesan, } \\
2005 ; \text { Roy et al., } \\
2018\end{array}$ & $\begin{array}{l}\text { Kumar \& } \\
\text { Venkatesan, 2005 }\end{array}$ \\
\hline $\begin{array}{l}\text { Buy more frequently } \\
\text { Expects more from shopping } \\
\text { experience, shopping experience } \\
\text { is more exploratory }\end{array}$ & $\begin{array}{l}\text { Mathwick et al., } \\
2002 ; \text { Kumar \& } \\
\text { Venkatesan, 2005 }\end{array}$ \\
\hline $\begin{array}{l}\text { Requires personalized content, } \\
\text { pay attention to recommenda- } \\
\text { tions }\end{array}$ & $\begin{array}{l}\text { Mosquera et al., } \\
2017\end{array}$ \\
\hline
\end{tabular}


In addition, it avoids potential consumer dissatisfaction if customers observe that they have paid higher prices for an item than other consumers (Brynjolfsson et al., 2011). What is more, omnichannel customers who are fully engaged through digital and social media tend to become very loyal (Cook, 2014).

\subsection{Online sales approach evaluation criteria}

Performance can be measured using quantitative and qualitative criteria. What is more, it is necessary to use both options because only quantitative - financial - outcome does not show full picture. Moreover, relying solely on financial performance criteria has been criticized by Neely et al., 2000; Nørreklit, 2000; Zuriekat, 2011. There is an expressed opinion existing in academic literature (Kaplan \& Norton, 1996; Kueng, 2000; Van Looy \& Shafagatova, 2016) about an obliged need to combine financial and non-financial criteria in order to find out overall situation about business performance outcome. In the case of this research the use of both quantitative (financial) and qualitative (customer based) criteria helps to evaluate relationship between online sales approach and generated performance outcome in a holistic way.

Batocchio et al. (2016) described revenues and costs as financial viability. Financial viability aspects (see Table 3) such as increased revenues, decreased costs, higher profit margin are easy measured because they are determined by direct rules and can be found in the financial statements or annual reports.

Table 3. Financial viability aspects (source: created by authors)

\begin{tabular}{|c|c|}
\hline Financial result & Author \\
\hline Increased revenues & $\begin{array}{l}\text { Batocchio et al., 2016; } \\
\text { Eklof et al., 2018; Saleem } \\
\text { et al., } 2019\end{array}$ \\
\hline Decreased costs & $\begin{array}{l}\text { Burnham et al., 2003; } \\
\text { Storbacka et al., 2009; } \\
\text { Goel et al., 2010; } \\
\text { Storbacka, 2019 }\end{array}$ \\
\hline Increased sales & $\begin{array}{l}\text { Bell et al., 2014; } \\
\text { Meiseberg, 2016 }\end{array}$ \\
\hline
\end{tabular}

All non-quantitative criteria are connected with customers and their experience during purchase process. An understanding of customer satisfaction must be a basic parameter used to evaluate the performance of products and services (Yang \& Feng-Shii Tsai, 2007). Customer connected criteria have significant impact on financial performance but these two different types cannot be acknowledged as substitutes. Non-financial performance evaluation criteria are used as additives to financial ones. Figure 1 shows an outline which logically emphasizes that financial results are affected by customer based results. Consequently, it is still necessary to address how non-financial performance criteria are related to the achievement of profit enhancement (Zuriekat, 2011).

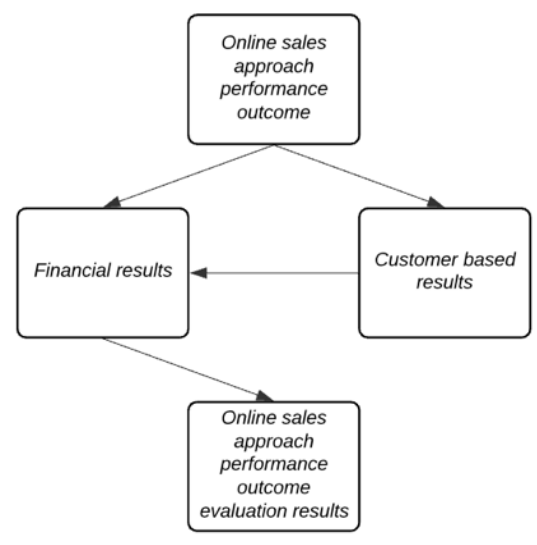

Figure 1. Outline of performance outcome evaluation (source: created by authors based on Eklof et al., 2018)

Table 4. Customer satisfaction attributes (source: created by authors)

\begin{tabular}{|l|l|}
\hline \multicolumn{1}{|c|}{ Attribute } & \multicolumn{1}{c|}{ Author } \\
\hline $\begin{array}{l}\text { Demonstration of loyal } \\
\text { behaviour (e-loyalty) }\end{array}$ & $\begin{array}{l}\text { Wangenheim \& Bay- } \\
\text { ón, 2004; Ghazali } \\
\text { et al., 2016 }\end{array}$ \\
\hline $\begin{array}{l}\text { Repurchasing or resistance } \\
\text { towards price increases }\end{array}$ & $\begin{array}{l}\text { Wangenheim \& } \\
\text { Bayón, 2004; Albert } \\
\text { et al., 2014 }\end{array}$ \\
\hline $\begin{array}{l}\text { Less intention in switching } \\
\text { provider }\end{array}$ & $\begin{array}{l}\text { Wangenheim \& } \\
\text { Bayón, 2004 }\end{array}$ \\
\hline $\begin{array}{l}\text { Loyalty affected by per- } \\
\text { ceived switching costs and } \\
\text { perceived attractiveness of } \\
\text { alternatives }\end{array}$ & Ghazali et al., 2016 \\
\hline $\begin{array}{l}\text { Online Word of Mouth } \\
\text { (OCR - online customer } \\
\text { reviews, comments, other } \\
\text { content creation) }\end{array}$ & $\begin{array}{l}\text { Wangenheim \& } \\
\text { Bayón, 2004; Hoskins } \\
\text { \& Brown, 2018 }\end{array}$ \\
\hline $\begin{array}{l}\text { Switching barriers on cus- } \\
\text { tomer retention }\end{array}$ & $\begin{array}{l}\text { Burnham et al., 2003; } \\
\text { Ghazali et al., 2016 }\end{array}$ \\
\hline Customer retention & $\begin{array}{l}\text { Ranaweera \& Prabhu, } \\
\text { 2003 }\end{array}$ \\
\hline $\begin{array}{l}\text { Increased engagement } \\
\text { Hoskins \& Brown, } \\
\text { 2018 }\end{array}$ \\
\hline
\end{tabular}

Understanding customer and his needs is a keystone concept in online business. Pure online players face harsh competition because competitors are just one click away (Ghazali et al., 2016). Companies have to adapt and focus on customer 
satisfaction because in the online world where negative reputation of product or entire company can be formed and spread out in seconds no mistakes can be done. Customer satisfaction received extant attention in academic research. Table 4 shows main attributes which are connected with customer satisfaction.

Customer satisfaction leads into loyal behaviour which turns into increased financial outcome. But customer satisfaction does not automatically predict loyalty (Ghazali et al., 2016). Satisfaction might be lower but loyalty to product or brand would remain (Pomirleanu et al., 2016).

\subsection{The concept of online sales approach and performance outcome relationship evaluation}

In decision making level sales channel choice is important for several reasons. Firstly, this decision is connected to the way how organization is going to reach its customers. Secondly, the channel choice determines organizational performance because not all online channels are equal and they generate different results. Channel integration can present both opportunities and threats, namely, channel integration can be performance enhancing and performance destroying (Herhausen et al., 2015).

Performance measurement is a multidisciplinary topic that is highly studied by both the management and business process management domains (Van Looy \& Shafagatova, 2016). For profit oriented companies performance is typically calculated objectively through measures of profitability (Hull \& Lio, 2006). Using different online channels or their integration (omnichannel retail) is in the topic for finding the best way to achieve this goal. The concept of online sales approach and performance relationship measurement is based on financial and customer satisfaction criteria. We are going to investigate three financial aspects - increased revenues, decreased costs and increased sales (see Table 3) in this research. Increased sales lead to increased revenues but it is important to pay attention to received order change (in order units) too. This performance measurement can be used for each online sales channel or for their integrated omnichannel model. Indicators describing financial criteria are shown in Table 5.

Online sales performance in social media is affected by s-commerce environment and depends on online customers reviews (Cui et al., 2012; Wang et al., 2015; Chong et al., 2016; Hoskins \& Brown, 2018; Li \& Shimizu, 2018). Online customer reviews are described by review valence and review volume.
Table 5. Financial indicators (source: created by authors)

\begin{tabular}{|c|c|c|}
\hline Indicator & Formula & Used by \\
\hline $\begin{array}{l}\text { Sales per- } \\
\text { formance }\end{array}$ & $\begin{array}{l}\text { Achieved total } \\
\text { sales/planned sales } \\
* 100\end{array}$ & $\begin{array}{l}\text { Balaban et al., } \\
2011\end{array}$ \\
\hline $\begin{array}{l}\text { Return on } \\
\text { sales (ROS) }\end{array}$ & $\begin{array}{l}\text { Average Net Prof- } \\
\text { it/Average Sales }\end{array}$ & $\begin{array}{l}\text { Awang et al., } \\
2010\end{array}$ \\
\hline $\begin{array}{l}\text { Average } \\
\text { order value }\end{array}$ & $\begin{array}{l}\text { Aggregated } \\
\text { monthly } \\
\text { sales/monthly no. } \\
\text { of orders }\end{array}$ & $\begin{array}{l}\text { Balaban et al., } \\
2011\end{array}$ \\
\hline $\begin{array}{l}\text { Net profit } \\
\text { margin }\end{array}$ & $\begin{array}{l}\text { After-tax profit or } \\
\text { loss/total operating } \\
\text { revenue }\end{array}$ & $\begin{array}{l}\text { Bosilj-Vuksic } \\
\text { et al., 2008; Wu, } \\
\text { 2012; Sun \& } \\
\text { Kim, } 2013\end{array}$ \\
\hline $\begin{array}{l}\text { Profit per } \\
\text { customer }\end{array}$ & $\begin{array}{l}\text { After-tax earn- } \\
\text { ings/total no. of } \\
\text { customers (or spe- } \\
\text { cific channel no. } \\
\text { of customers) }\end{array}$ & Wu, 2012 \\
\hline $\begin{array}{l}\text { Revenue } \\
\text { growth }\end{array}$ & $\begin{array}{l}\text { Revenue from new } \\
\text { sources/total reve- } \\
\text { nue } * 100\end{array}$ & $\begin{array}{l}\text { Bosilj-Vuksic } \\
\text { et al., } 2008\end{array}$ \\
\hline $\begin{array}{l}\text { Return on } \\
\text { investment } \\
(\mathrm{ROI})\end{array}$ & $\begin{array}{l}\text { Revenue - } \\
\text { cost/cost }\end{array}$ & $\begin{array}{l}\text { Goel et al., } \\
\text { 2010; Wu, } 2012\end{array}$ \\
\hline $\begin{array}{l}\text { Return on } \\
\text { assets } \\
\text { (ROA) }\end{array}$ & $\begin{array}{l}\text { After-tax profit or } \\
\text { loss]/[average total } \\
\text { assets }\end{array}$ & $\begin{array}{l}\text { Bosilj-Vuksic } \\
\text { et al., 2008; Wu, } \\
\text { 2012; Sun \& } \\
\text { Kim, 2013; } \\
\text { Eklof et al., } \\
2018\end{array}$ \\
\hline
\end{tabular}

Service quality in particular has repeatedly proven to be a key indicator of customer satisfaction, which in turn has a positive impact on customer loyalty (Brusch et al., 2019). The SERVQUAL (Parasuraman et al., 1985) model is known as a generic instrument for service quality measurement but in e-commerce environment configurated model is needed. Two scales are used to examine online customer satisfaction and online customer loyalty - multiple-item scale called E-SQUAL (Parasuraman et al., 2005) and second multiple-item scale called E-RecS-QUAL (Parasuraman et al., 2005). These scales (see Figure 2) are used to measure the quality of electronic services of online shops. Four dimensions (efficiency, fulfillment, system availability, privacy) are covered by E-S-QUAL scale. The E-RecS-Qual scale, which is used to measure experiences of users who are new to online shopping, consists of three dimensions: responsiveness, compensation and contact (Brusch et al., 2019). 


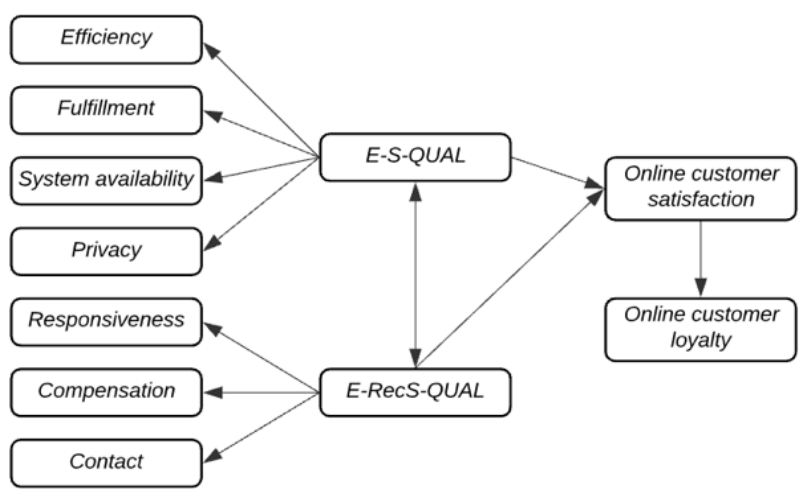

Figure 2. Online customer satisfactions and online customer loyalty measurement scales (source: created by authors based on Parasuraman et al., 2005)

\subsection{The concept of niche product}

A growth in people's interest for niche products more individualized products tailored to the needs of a very specific target group rather than to the mass market - has been observed for the past years and has received widespread attention (Simonson, 2005; Schaefers, 2014; Keskin et al., 2017).

Niche product has several distinctive attributes which are shown in Table 6. These attributes are grouped into 4 groups: customer oriented, market oriented, product oriented, IT oriented. This classification helps to investigate niche product from different angles and see full difference if compared to mainstream products.

Table 6. Attributes about niche product (source: created by authors)

\begin{tabular}{|c|c|c|}
\hline Attribute & Orientation & Author \\
\hline Low market share, limited market & Market & $\begin{array}{l}\text { Dalgic \& Leeuw, 1994; Jarvis \& Goodman, } \\
\text { 2005; Oberholzer-Gee \& Strumpf, 2007; } \\
\text { Toften \& Hammervoll, 2009; Son et al., } \\
2017\end{array}$ \\
\hline Very specific target group, customer focused & Customer & $\begin{array}{l}\text { Dalgic \& Leeuw, 1994; Jarvis \& Goodman, } \\
\text { 2005; Simonson, 2005; Toften \& Hammer- } \\
\text { voll, 2010; Schaefers, 2014; Keskin et al., } \\
\text { 2017; Aiolfi \& Sabbadin, 2019 }\end{array}$ \\
\hline High product quality & Product & Toften \& Hammervoll, 2010 \\
\hline Faultless reputation & Product & Toften \& Hammervoll, 2010 \\
\hline More profitable & $\begin{array}{l}\begin{array}{l}\text { Product/ } \\
\text { market }\end{array} \\
\end{array}$ & $\begin{array}{l}\text { Dalgic \& Leeuw, 1994; Jarvis \& Goodman, } \\
2005\end{array}$ \\
\hline Higher price & Product & $\begin{array}{l}\text { Dalgic \& Leeuw, 1994; Jarvis \& Goodman, } \\
\text { 2005; Darban, } 2019\end{array}$ \\
\hline Less competition & Market & Darban, 2019 \\
\hline $\begin{array}{l}\text { Discovery through both active (sampling) and pas- } \\
\text { sive (recommender systems - hyperlinks, co-pur- } \\
\text { chase, free trials) search or mix of both options - } \\
\text { user generated content (customer's product reviews, } \\
\text { online communities, comments in social media) }\end{array}$ & IT & $\begin{array}{l}\text { Brynjolfsson et al., 2006; Chevalier \& } \\
\text { Mayzlin, 2006; Venkatesh et al., 2012; } \\
\text { Meiseberg, } 2016\end{array}$ \\
\hline Second order, positive feedback effect & Customer & Brynjolfsson et al., 2006 \\
\hline Increased product variety market & Market & $\begin{array}{l}\text { Brynjolfsson et al., 2006; Brynjolfsson et al., } \\
\text { 2011; Venkatesh et al., 2012 }\end{array}$ \\
\hline Increased information about product & IT & Brynjolfsson et al., 2006 \\
\hline $\begin{array}{l}\text { Surplus gains from increased product variety rather } \\
\text { than from lower prices. }\end{array}$ & Product & Brynjolfsson et al., 2006 \\
\hline $\begin{array}{l}\text { IT enabled tools for search (Web 2.0, information } \\
\text { sharing and social networking) }\end{array}$ & IT & Brynjolfsson et al., 2006 \\
\hline Unavailable through conventional channels & Product & Brynjolfsson et al., 2011 \\
\hline Online market & Market & Brynjolfsson et al., 2011 \\
\hline Higher customer loyalty & Customer & Jarvis \& Goodman, 2005; Meiseberg, 2016 \\
\hline Low purchase frequency & Market & Jarvis \& Goodman, 2005; Meiseberg, 2016 \\
\hline Difficult for competitors to copy & Product & Toften \& Hammervoll, 2010 \\
\hline Building long-term and strong relationships & Customer & Dalgic \& Leeuw, 1994 \\
\hline Customization & Customer & Toften \& Hammervoll, 2010 \\
\hline Decreased search cost & IT & Meiseberg, 2016 \\
\hline
\end{tabular}


In general, customers tend to be more interested in mainstream products but internet channel is able to change this situation by several means. First of all, internet channel opens wider market which is not limited by region. Online seller can offer niche products globally for customers with different needs compared to mainstream mass. Niche companies are targeting smaller mass of users and markets (Darban, 2019). Having in mind saturated and difficult to enter mature markets, wider market gives more opportunities. Online channel also eliminates physical restriction for product quantities to be held on the shelves. Second, offering niche products means knowing as much as possible about your customer. Schaefers (2014) declared importance of identifying customers who are prone to purchase niche products as a vital activity. Customization, long term relationships with customers, additional attention and information provided before and after sales transaction, splendid product quality help to create user experience which leads to customer loyalty, customer satisfaction, creates willingness to write positive online reviews on the selling platforms and positive comments throughout social media networks. These aspects turn to repeated purchases and positively increased financial performance. And on contrary, lack of understanding your customer's profile and average or even poor product quality lead to destruction of reputation, negative online reviews or comments.

Word of mouth in online niche market is more valuable compared to traditional retailing of mainstream products because online user reviews have become an important source of information to consumers, substituting and complementing other forms of communication about product quality (Chevalier \& Mayzlin, 2006).

Niche products providing organizations generally experience higher customer satisfaction and loyalty rates than the average organization within their industry setting (Brynjolfsson et al., 2011) because of closer contact and deeper customer engagement. However, due to their small size of operations, niche organizations are notoriously cost inefficient and are thus unable to competitively position themselves in the marketplace to win on lower prices (Noy, 2010). This is why positive word of mouth on the internet plays even more important role.

\subsection{Framework for evaluating the relationship between the omnichannel online sales approach and the performance outcome in the case of niche products}

Systematic analysis of academic literature helped to identify online sales approach as a specific action workflow combined with digital interaction and the use of knowledge about customer's preferences alongside different selling channels in order to reach customer and create value together while completing sales process on the internet. Online sales approach can be understood as a specific channel which converts leads into closed sales in a value creating way. To simplify, online sales channel can be described as a way which connects seller and buyer. Integrated use of different channels is called omnichannel sales approach. In online omnichannel environment all channels are integrated together and offer holistic customer experience which leads to customer satisfaction and loyalty. Later these customer based performance results are converted into financial results.

In the case of niche products manufacturer is usually a retailer and wholesaler (if wholesale option is provided) at the same time. Manufacturer directly reaches end customer through online sales channel. This connection is displayed at the top section of the proposed framework (see Figure 3).

The selection of online sales approach is shown below and together with manufacturer-end customer connection forms a part of online sales process which is under investigation in this research.

Further systematic analysis of academic literature helped to identify financial and non-financial criteria which are used for performance outcome measurement. Financial outcome (revenues, costs, sales) and non-financial outcome (customer satisfaction and loyalty) are distinguished into two dotted blocks and characterized by relevant indicators. Financial and non-financial outcomes have a direct impact on performance outcome evaluation. Moreover, financial outcome is affected by nonfinancial outcome, so non-financial outcome has to be evaluated carefully. Performance outcome evaluation results are gathered after complex investigation of financial and non-financial outcome and their impact is done. These results have to be used in decision making process when deciding which online sales channel has to be chosen. Online sales channel cannibalization effect may occur. This effect can be found during performance evaluation process and needs to be eliminated in order to 
achieve better customer satisfaction and financial performance results.
Created and proposed theoretical framework can be used unlimited number of times, for each online sales channel or their integration.

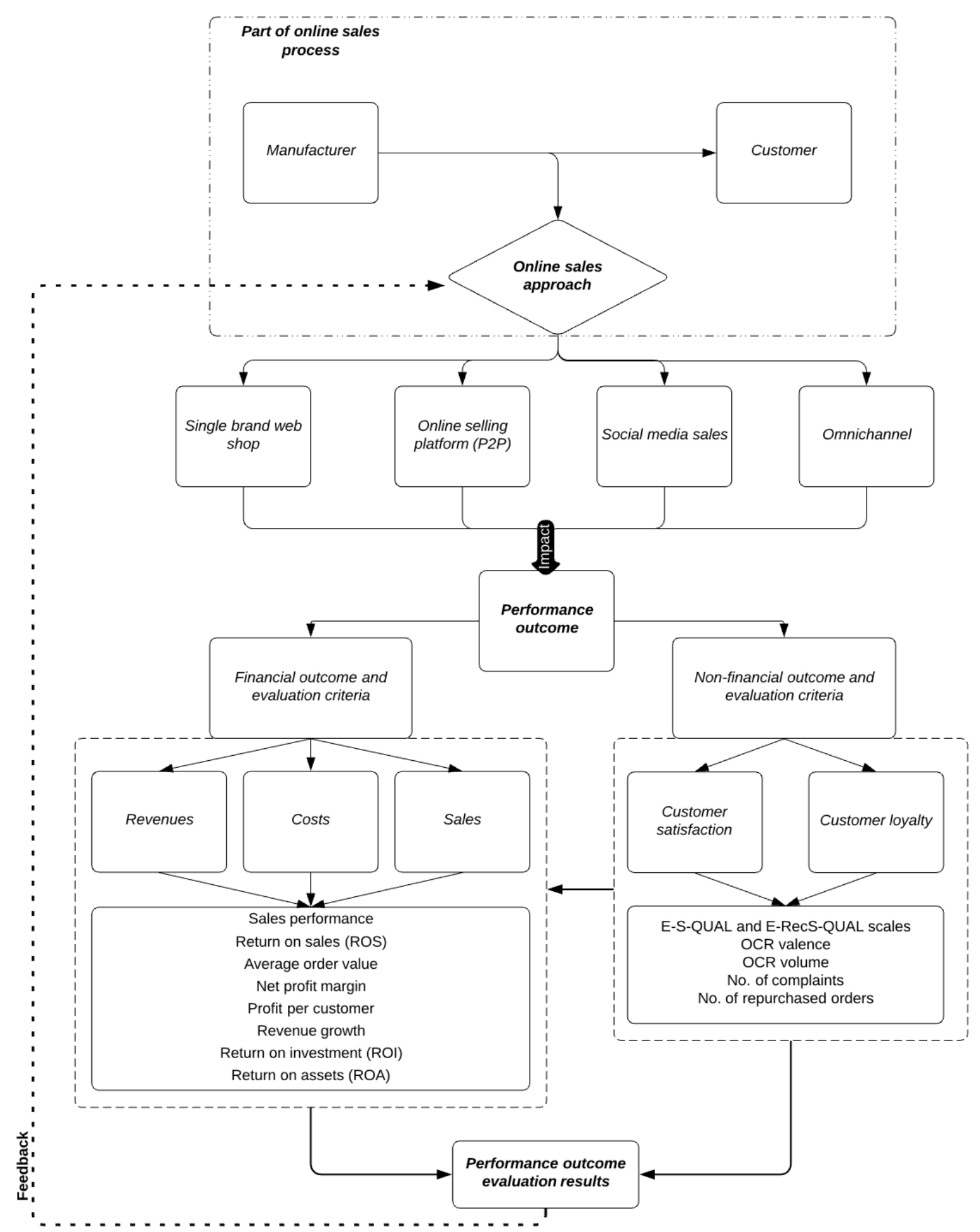

Figure 3. Framework for evaluating the relationship between the omnichannel online sales approach and the performance outcome in the case of niche products (source: Neely et al., 2000; Burnham et al., 2003; Wangenheim \& Bayón, 2004; Parasuraman et al., 2005; Kaplan \& Haenlein, 2010; Cui et al., 2012; Albert et al., 2014; Chong et al., 2016; Li et al., 2016; Eklof et al., 2018; Hoskins \& Brown, 2018) 


\section{Conclusions}

After systematic academic literature analysis about online sales approaches in the case of niche products three different channels (single brand web shop, selling platform, social media sales) and their integration called omnichannel sales approach were explored. The following conclusions can be presented.

First, each online sales approach proposed in this framework was accurately described. Single brand web shop is defined as online retail channel where a customer can order a product via a webbased portal. Online selling platform (P2P) is described as two-sided platform connecting two different parties and charging one or more of them a fee for this facilitation. Especially suitable for niche products. Social media sales - engagement with customers through non-transactional customer activities such as review writing. Omnichannel sales approach - synergetic integration of channels related to a holistic brand experience. In the case of niche product manufacturer directly connects with end customer through online sales channels.

Second, created framework presents how online sales approach can be evaluated by financial (revenues, costs, sales) and non-financial (customer satisfaction and loyalty) criteria. These both types of criteria are important for the final evaluation of results. What is more, non-financial evaluation criteria have directly impact on financial outcome and have to be evaluated carefully. This aspect has an extremely important impact for niche products offering companies due to specifics of this segment.

Third, the concept of online sales approach and performance relationship evaluation in the case of niche products is based on financial and customer satisfaction criteria. Three financial aspects - increased revenues, decreased costs and increased sales are investigated in this concept. The above mentioned aspects are characterized by these indicators: sales performance, return on sales (ROS), average order value, net profit margin, profit per customer, revenue growth, return on investment (ROI) and return on assets (ROA). E-SQUAL and E-RecS-QUAL scales together with online customer reviews volume and online customer reviews valence, number of complaints, number of repurchased orders are integrated in non-financial outcome evaluation. This performance evaluation can be used for each online sales channel or for their integrated omnichannel online sales approach. After online sales approach and performance relationship evaluation results are received they are used in decision making process while reconsidering sales channel if it is necessary or if cannibalization effect occurs.

Finally, the framework for evaluating the relationship between the omnichannel online sales approach and performance outcome in the case of niche products is proposed. This model shows through which channel or their integration (omnichannel) seller can reach his end customer. In the case of niche product manufacturer contacts with his customer directly through online sales channels. This theoretical framework combines financial and non-financial evaluation criteria. The complexity of the theoretical framework shows direct impact of financial criteria on online sales approach and performance relationship evaluation results and also indicates non-financial criteria impact on financial outcome. Performance outcome evaluation results are used in decision making process when deciding which online sales channel or their integration has to be chosen, has to be replaced due to occurred effect of channel cannibalization or has to be eliminated.

\section{Limitations and future research}

The proposed framework for evaluating the relationship between omnichannel online sales approach and performance outcome in the case of niche products can be discussed as a starting point for further analysis. Notwithstanding, we declare several limitations connected to our proposed framework.

First, this is a theoretical model which was created after systematic analysis of recent academic literature; however, it has not been tested empirically yet.

Second, the financial outcome could be investigated in a broader perspective by incorporating a wider number of criteria than those which have been used. Three different aspects of financial outcome have been chosen having in mind that companies which are offering niche products usually pay attention mainly to these aspects; however, the framework can be expanded without creating any disadvantage.

The third limitation refers to the cannibalization effect which could be investigated as a separate topic in future research.

We strongly believe that this model is detailed enough and can be easily interpreted or implemented if needed; however, an additional opportunity for future research would be to refine the framework for a wider range of cases. 


\section{Managerial implications}

The most important aspect of our framework is the ability to use it at the managerial level for decision making. These decisions are connected to the appropriate choice of channel selection or its full integration into omnichannel online sales approach which leads to a holistic customer experience (Mosquera, Olarte Pascual and Juaneda Ayensa, 2017), targeted customer groups with tailored offers (Hernant \& Rosengren, 2017) or decreased customer retention rate (Boehm, 2008). Managers of niche products can use this framework while adapting financial or/and non-financial outcome evaluation criteria as key performance indicators. After receiving conclusions about channel performance, the cannibalization effect can be discovered straightforward.

\section{References}

Aiolfi, S., \& Sabbadin, E. (2019). Fashion and new luxury digital disruption: the new challenges of fashion between omnichannel and traditional retailing. International Journal of Business and Management, 14(8), 41-51. https://doi.org/10.5539/ijbm.v14n8p41

Albert, L. J., Aggarwal, N., \& Hill, T. R. (2014). Influencing customer's purchase intentions through firm participation in online consumer communities. Electronic Markets, 24(4), 285-295. https://doi.org/10.1007/s12525-014-0169-3

Andzulis, J., Panagopoulos, N. G., \& Rapp, A. (2012). A review of social media and implications for the sales process. Journal of Personal Selling and Sales Management, 32(3), 305-316. https://doi.org/10.2753/PSS0885-3134320302

Awang, A., Said Asghar, A. R., \& Subari, K. A. (2010). Study of distinctive capabilities and entrepreneurial orientation on return on sales among Small and Medium Agro-Based Enterprises (SMAEs) in Malaysia. International Business Research, 3(2), 34-48. https://doi.org/10.5539/ibr.v3n2p34

Baghdadi, Y. (2016). A framework for social commerce design. Information Systems, 60, 95-113. https://doi.org/10.1016/j.is.2016.03.007

Balaban, N., Belić, K., \& Gudelj, M. (2011). Business process performance management: theoretical and methodological approach and implementation. Management Information Systems, 6(4), 3-9.

Batocchio, A., Ghezzi, A., \& Rangone, A. (2016). A method for evaluating business models implementation process. Business Process Management Journal, 22(4), 712-735. https://doi.org/10.1108/BPMJ-08-2015-0117

Beck, N., \& Rygl, D. (2015). Categorization of multiple channel retailing in Multi-, Cross-, and Omni-
Channel Retailing for retailers and retailing. Journal of Retailing and Consumer Services, 27, 170-178.

https://doi.org/10.1016/j.jretconser.2015.08.001

Bernard, G., Boillat, T., Legner, C., \& Andritsos, P. (2016). When sales meet process mining: A scientific approach to sales process and performance management. In 2016 International Conference on Information Systems, ICIS 2016 (pp. 111).

Bell, D. R., Gallino, S., \& Antonio Moreno, A. (2014). How to win in an omnichannel world. MIT Sloan Management Review, 56(1), 45-53.

Berthon, P. R., Pitt, L. F., Plangger, K., \& Shapiro, D. (2012). Marketing meets Web 2.0, social media, and creative consumers: Implications for international marketing strategy. Business Horizons, 55(3), 261-271.

https://doi.org/10.1016/j.bushor.2012.01.007

Bocconcelli, R., Cioppi, M., \& Pagano, A. (2017). Social media as a resource in SMEs' sales process. Journal of Business and Industrial Marketing, 32(5), 693-709.

https://doi.org/10.1108/JBIM-11-2014-0244

Boehm, M. (2008). Determining the impact of internet channel use on a customer's lifetime. Journal of Interactive Marketing, 22(3), 2-22.

https://doi.org/10.1002/dir.20114

Bosilj-Vuksic, V., Milanovic, L., Skrinjar, R., \& Indihar-Stemberger, M. (2008). Organizational performance measures for business process management: A performance measurement guideline. In 10th International Conference on Computer Modelling and Simulation (UKSim 2008) (pp. 94-99). https://doi.org/10.1109/UKSIM.2008.114

Brusch, I.-S., Schwarz, B., \& Schmitt, R. (2019). David versus Goliath - Service quality factors for niche providers in online retailing. Journal of Retailing and Consumer Services, 50, 266-276. https://doi.org/10.1016/j.jretconser.2019.05.008

Brynjolfsson, E., Hu, Y. J., \& Smith, M. D. (2006). From niches to riches: the anatomy of the long tail. http://repository.cmu.edu/heinzworks/51

Brynjolfsson, E., Hu, Y. J., \& Simester, D. (2011). Goodbye Pareto principle, hello long tail: The effect of search costs on the concentration of product sales. Management Science, 57(8), 13731386. https://doi.org/10.1287/mnsc.1110.1371

Burnham, T. A., Frels, J. K., \& Mahajan, V. (2003). Consumer switching costs: A typology, antecedents, and consequences. Journal of the Academy of Marketing Science, 31(2), 109-126. https://doi.org/10.1177/0092070302250897

Chandna, V., \& Salimath, M. S. (2018). Peer-to-peer selling in online platforms: A salient business model for virtual entrepreneurship. Journal of Business Research, 84, 162-174. https://doi.org/10.1016/j.jbusres.2017.11.019 
Chevalier, J. A., \& Mayzlin, D. (2006). The effect of word of mouth on sales: Online book reviews. Journal of Marketing Research, 43(3), 345-354. https://doi.org/10.1509/jmkr.43.3.345

Chong, A. Y. L., Li, B., Ngai, E. W. T., Ch'ng, E., \& Lee, F. (2016). Predicting online product sales via online reviews, sentiments, and promotion strategies: A big data architecture and neural network approach. International Journal of Operations and Production Management, 36(4), 358-383. https://doi.org/10.1108/IJOPM-03-2015-0151

Constantinides, E., Romero, C. L., \& Boria, M. A. G. (2009). Social media: a new frontier for retailers? In B. Swoboda, D. Morschett, T. Rudolph, P. Schnedlitz, H., \& Schramm-Klein (Eds.), European retail research (Vol. 22, pp. 1-28).

Cook, G. (2014). Customer experience in the omnichannel world and the challenges and opportunities this presents. Journal of Direct, Data and Digital Marketing Practice, 15(4), 262-266. https://doi.org/10.1057/dddmp.2014.16

Cooper, M. J., \& Budd, C. S. (2007). Tying the pieces together: A normative framework for integrating sales and project operations. Industrial Marketing Management, 36(2), 173-182. https://doi.org/10.1016/j.indmarman.2006.03.005

Cui, G., Lui, H. K., \& Guo, X. (2012). The effect of online consumer reviews on new product sales. International Journal of Electronic Commerce, 17(1), 39-57. https://doi.org/10.2753/JEC1086-4415170102

Cummins, S., Peltier, J. W., \& Dixon, A. (2016). Omnichannel research framework in the context of personal selling and sales management: A review and research extensions. Journal of Research in Interactive Marketing, 10(1), 2-16. https://doi.org/10.1108/JRIM-12-2015-0094

Dalgic, T., \& Leeuw, M. (1994). Niche marketing revisited: concept, applications and some European cases. European Journal of Marketing, 28(4), 3955. https://doi.org/10.1108/03090569410061178

Darban, M. (2019). How niche is niche? Measuring individuals' perception of technology niche. In Proceedings of the 52nd Hawaii International Conference on System Sciences (Vol. 6, pp. 51135122. https://doi.org/10.24251/HICSS.2019.614

Eklof, J., Podkorytova, O., \& Malova, A. (2018). Linking customer satisfaction with financial performance: an empirical study of Scandinavian banks. Total Quality Management and Business Excellence, 1-19. https://doi.org/10.1080/14783363.2018.1504621

Falk, M., \& Hagsten, E. (2015). E-commerce trends and impacts across Europe. International Journal of Production Economics, 170, 357-369. https://doi.org/10.1016/j.ijpe.2015.10.003

Ferrell, L., Gonzalez-Padron, T., \& Ferrell, O. (2010). An assessment of the use of technology in the direct selling industry. Journal of Personal Selling and Sales Management, 30(2), 157-165.

https://doi.org/10.2753/PSS0885-3134300206

Fotiadis, A. K., \& Stylos, N. (2017). The effects of online social networking on retail consumer dynamics in the attractions industry: The case of "E-da" theme park, Taiwan. Technological Forecasting and Social Change, 124, 283-294.

https://doi.org/10.1016/j.techfore.2016.06.033

Gerrikagoitia, J. K., Castandera, I., Rebóna, F., \& Alzua-Sorzabala, A. (2015). New trends of intelligent e-marketing based on web mining for eshops. Procedia - Social and Behavioral Sciences, 175, 75-83. https://doi.org/10.1016/j.sbspro.2015.01.1176

Ghazali, E. Nguyen, B., Mutum, D. S., \& Amrul Asraf Mohd-Any. (2016). Constructing online switching barriers: examining the effects of switching costs and alternative attractiveness on e-store loyalty in online pure-play retailers. Electronic Markets, 26(2), 157-171. https://doi.org/10.1007/s12525-016-0218-1

Goel, S., Broder, A., Gabrilovich, E., \& Pang, B. (2010). Anatomy of the long tail: Ordinary people with extraordinary tastes. In WSDM 2010 Proceedings of the 3rd ACM International Conference on Web Search and Data Mining (pp. 201-210). https://doi.org/10.1145/1718487.1718513

Hajli, N., Wang, Y., Tajvidi, M., \& Hajli, M. S. (2017). People, technologies, and organizations interactions in a social commerce era. IEEE Transactions on Engineering Management, 64(4), 594-604. https://doi.org/10.1109/TEM.2017.2711042

Hansen, R., \& Sia, S. K. (2015). Hummel's digital transformation toward omnichannel retailing: Key lessons learned. MIS Quarterly Executive, 14(2), 51-66.

Herhausen, D., Binder, J., Schoegel, M., \& Herrmann, A. (2015). Integrating bricks with clicks: retailer-level and channel-level outcomes of online-offline channel integration. Journal of Retailing, 91(2), 309-325. https://doi.org/10.1016/j.jretai.2014.12.009

Hernant, M., \& Rosengren, S. (2017). Now what? Evaluating the sales effects of introducing an online store. Journal of Retailing and Consumer Services, 39, 305-313. https://doi.org/10.1016/j.jretconser.2017.08.010

Hoskins, J. D., \& Brown, B. A. (2018). On the contrasting strategic impact of online customer reviews for niche and mainstream organizations: Evidence from US higher education. Journal of Research in Interactive Marketing, 12(3), 347369. https://doi.org/10.1108/JRIM-01-2018-0015

Huang, Z. et al. (2016). Brand co-creation through social commerce information sharing: The role of 
social media. Journal of Business Research, 69, $246-259$.

Huang, Z., \& Benyoucef, M. (2013). From e-commerce to social commerce: A close look at design features. Electronic Commerce Research and Applications, 12(4), 246-259.

https://doi.org/10.1016/j.elerap.2012.12.003

Hull, C. E., \& Lio, B. H. (2006). Innovation in nonprofit and for-profit organizations: Visionary, strategic, and financial considerations. Journal of Change Management, 6(1), 53-65. https://doi.org/10.1080/14697010500523418

Huré, E., Picot-Coupey, K., \& Ackermann, C. L. (2017). Understanding omni-channel shopping value: A mixed-method study. Journal of Retailing and Consumer Services, 39, 314-330.

https://doi.org/10.1016/j.jretconser.2017.08.011

Jarvis, W., \& Goodman, S. (2005). Effective marketing of small brands: Niche positions, attribute loyalty and direct marketing. Journal of Product and Brand Management, 14(5), 292-299. https://doi.org/10.1108/10610420510616322

Jelassi, T., \& Leenen, S. (2003). An e-commerce sales model for manufacturing companies: A Conceptual framework and a European example. European Management Journal, 21(1), 38-47. https://doi.org/10.1016/S0263-2373(02)00151-2

Kaplan, A. M., \& Haenlein, M. (2010). Users of the world, unite! The challenges and opportunities of Social Media. Business Horizons, 53(1), 59-68. https://doi.org/10.1016/j.bushor.2009.09.003

Kaplan, R. S., \& Norton, D. P. (1996). Strategic Learning \& the Balanced Scorecard. Strategy \& Leadership, 24(5), 18-24. https://doi.org/10.1108/eb054566

Kabasakal, I., Keskin, F. D., Ventura, K., \& Soyuer, H. (2017). From mass customization to product personalization in automotive industry: potentials of industry 4.0. Pressacademia, 4(3), 244-250. https://doi.org/10.17261/Pressacademia.2017.486

Kim, C., \& Takashima, K. (2019). Effects of retail organisation design on improving private label merchandising. European Journal of Marketing, 53(12), 2582-2603 https://doi.org/10.1108/EJM-03-2018-0194

Kim, D. (2013). Under what conditions will social commerce business models survive? Electronic Commerce Research and Applications, 12(2), 6977. https://doi.org/10.1016/j.elerap.2012.12.002

Kueng, P. (2000). Process performance measurement system: A tool to support process-based organizations. Total Quality Management, 11(1), 67-85. https://doi.org/10.1080/0954412007035

Kumar, V., \& Venkatesan, R. (2005). Who are the multichannel shoppers and how do they perform?: Correlates of multichannel shopping behavior. Journal of Interactive Marketing, 19(2), 44-62. https://doi.org/10.1002/dir.20034
Lapoule, P., \& Colla, E. (2016). The multi-channel impact on the sales forces management. International Journal of Retail and Distribution Management, 44(3), 248-265. https://doi.org/10.1108/IJRDM-11-2014-0159

Lee, Z. W. Y., Chan, T. K. H., Yee-LoongChong, A., \& Thadani, D. R. (2019). Customer engagement through omnichannel retailing: The effects of channel integration quality. Industrial Marketing Management, 77, 90-101. https://doi.org/10.1016/j.indmarman.2018.12.004

Li, B., Ch'ng, E., Yee-LoongChong, A., \& Bao, H. (2016). Predicting online e-marketplace sales performances: A big data approach. Computers and Industrial Engineering, 101, 565-571. https://doi.org/10.1016/j.cie.2016.08.009

Li, Z., \& Shimizu, A. (2018). Impact of online customer reviews on sales outcomes: an empirical study based on prospect theory. The Review of Socionetwork Strategies, 12(2), 135-151. https://doi.org/10.1007/s12626-018-0022-9

Mačiulienè, M., \& Skaržauskienė, A. (2016). Evaluation of co-creation perspective in networked collaboration platforms. Journal of Business Research, 69(11), 4826-4830. https://doi.org/10.1016/j.jbusres.2016.04.038

Mathwick, C., Malhotra, N. K., \& Rigdon, E. (2002). The effect of dynamic retail experiences on experiential perceptions of value: An Internet and catalog comparison. Journal of Retailing, 78(1), 51-60.

https://doi.org/10.1016/S0022-4359(01)00066-5

Meiseberg, B. (2016). The Effectiveness of e-tailers' communication practices in stimulating sales of niche versus popular products. Journal of Retailing, 92(3), 319-332.

https://doi.org/10.1016/j.jretai.2016.02.002

Mosquera, A., Olarte Pascual, C., \& Juaneda Ayensa, E. (2017). Understanding the customer experience in the age of omni-channel shopping. Revista ICONO14 Revista científica de Comunicación y Tecnologías emergentes, 15(2), 92-114. https://doi.org/10.7195/ri14.v15i2.1070

Neely, A. Mills, J., Platts, K., Richards, H., Gregory, M., Bourne, M., \& Kennerley, M. (2000). Performance measurement system design: Developing and testing a process-based approach. International Journal of Operations and Production Management, 20(10), 1119-1145. https://doi.org/10.1108/01443570010343708

Nørreklit, H. (2000). The balance on the balanced scorecard a critical analysis of some of its assumptions. Management Accounting Research, 11(1), 65-88. https://doi.org/10.1006/mare.1999.0121

Noy, E. (2010). Niche strategy: Merging economic and marketing theories with population ecology arguments. Journal of Strategic Marketing, 18(1), 77-86.

https://doi.org/10.1080/09652540903511324 
Oberholzer-Gee, F., \& Strumpf, K. (2007). The effect of file sharing on record sales: an empirical analysis. Journal of Political Economy, 115(1), 1-42. https://doi.org/10.1086/511995

Parasuraman, A., Zeithaml, V. A., \& Berry, L. L. (1985). A conceptual model of service quality and its implications for future research. Journal of Marketing, 49(4), 41-50. https://doi.org/10.1177/002224298504900403

Parasuraman, A., Zeithaml, V. A., \& Malhotra, A. (2005). E-S-QUAL a multiple-item scale for assessing electronic service quality. Journal of Service Research, 7(3), 213-233. https://doi.org/10.1177/1094670504271156

Parisot, O., Vierke, G., Tamisier, T., Didry, Y., \& Rieder, H. (2014). Visual analytics for supporting manufacturers and distributors in online sales. In Lecture Notes in Informatics (LNI), Proceedings Series of the Gesellschaft fur Informatik (GI) (pp. 133-144).

Parvinen, P., Oinas-Kukkonen, H., \& Kaptein, M. (2015). E-selling: A new avenue of research for service design and online engagement. Electronic Commerce Research and Applications, 14(4), 214221. https://doi.org/10.1016/j.elerap.2014.10.007

Pentina, I., Gammoh, B. S., Zhang, L., \& Mallin, M. (2013). Drivers and outcomes of brand relationship quality in the context of online social networks. International Journal of Electronic Commerce, 17(3), 63-86. https://doi.org/10.2753/JEC1086-4415170303

Pomirleanu, N., Chennamaneni, P. R., \& Krishen, A. S. (2016). Easy to please or hard to impress: Elucidating consumers' innate satisfaction. Journal of Business Research, 69(5), 1914-1918. https://doi.org/10.1016/j.jbusres.2015.10.079

Ranaweera, C., \& Prabhu, J. (2003). The influence of satisfaction, trust and switching barriers on customer retention in a continuous purchasing setting. International Journal of Service Industry Management, 14(3-4), 374-395. https://doi.org/10.1108/09564230310489231

Rippé, C. B. (2015). Show and sell: teaching sales through hands-on selling. Marketing Education Review, 25(1), 15-19. https://doi.org/10.1080/10528008.2015.999595

Roy, S. K., Balaji, M. S., Quazi, A., \& Quaddus, M. (2018). Predictors of customer acceptance of and resistance to smart technologies in the retail sector. Journal of Retailing and Consumer Services, 42, 147-160. https://doi.org/10.1016/j.jretconser.2018.02.005

Saleem, H. M., Uddin, K. S., Habib-ur-Rehman, S., Saleem, S., \& Aslam, A. M. (2019). Strategic data driven approach to improve conversion rates and sales performance of e-commerce websites. International Journal of Scientific \& Engineering Research, 10(4), 588-593. http://www.ijser.org
Schaefers, T. (2014). Standing out from the crowd: Niche product choice as a form of conspicuous consumption. European Journal of Marketing, 48(9), 1805-1827. https://doi.org/10.1108/EJM-03-2013-0121

Simonson, I. (2005). Determinants of customers' responses to customized offers: Conceptual framework and research propositions. Journal of Marketing, 69(1), 32-45. https://doi.org/10.1509/jmkg.69.1.32.55512

Son, J., Kim, J. J., Choi, J., \& Kim, M. (2017). Linking online niche sales to offline brand conditions. Journal of Business Research, 70, 74-84. https://doi.org/10.1016/j.jbusres.2016.07.004

Song, J., Baker, J., Lee, S., \& Wetherbe, J. C. (2012). Examining online consumers' behavior: A serviceoriented view. International Journal of Information Management, 32(3), 221-231. https://doi.org/10.1016/j.ijinfomgt.2011.11.002

Song, J., \& Zahedi, F. (2005). A theoretical approach to Web design in e-commerce: A belief reinforcement model. Management Science, 51(8), 12191235. https://doi.org/10.1287/mnsc.1050.0427

Sriram, S., Manchanda, P., Bravo, M. E., Chu, J., Ma, L., Song, M., Shriver, S., \& Subramanian, U. (2015). Platforms: a multiplicity of research opportunities. Marketing Letters, 26(2), 141-152. https://doi.org/10.1007/s11002-014-9314-1

Storbacka, K., Ryals, L., Davies, I. A., \& Nenonen, S. (2009). The changing role of sales: Viewing sales as a strategic, cross-functional process. European Journal of Marketing, 43(7), 890-906. https://doi.org/10.1108/03090560910961443

Storbacka, K. (2019). Actor engagement, value creation and market innovation. Industrial Marketing Management, 80, 4-10. https://doi.org/10.1016/j.indmarman.2019.04.007

Sun, K. A., \& Kim, D. Y. (2013). Does customer satisfaction increase firm performance? An application of American Customer Satisfaction Index (ACSI). International Journal of Hospitality Management, 35, 68-77. https://doi.org/10.1016/j.ijhm.2013.05.008

Tajvidi, M., Richard, M.-O., Wang,Y. C., \& Hajli, N. (2018). Brand co-creation through social commerce information sharing: The role of social media. Journal of Business Research, 1-11. https://doi.org/10.1016/j.jbusres.2018.06.008

Toften, K., \& Hammervoll, T. (2009). Niche firms and marketing strategy: An exploratory study of internationally oriented niche firms. European Journal of Marketing, 43(11), 1378-1391. https://doi.org/10.1108/03090560910989948

Toften, K., \& Hammervoll, T. (2010). Niche marketing and strategic capabilities: An exploratory study of specialised firms. Marketing Intelligence and Planning, 28(6), 736-753. https://doi.org/10.1108/02634501011078138 
Van Looy, A., \& Shafagatova, A. (2016). Business process performance measurement: a structured literature review of indicators, measures and metrics. SpringerPlus, 5(1), 1-24. https://doi.org/10.1186/s40064-016-3498-1

Verhoef, P. C., Kannan, P. K., \& Inman, J. J. (2015). From multi-channel retailing to omni-channel retailing: Introduction to the Special Issue on Multi-Channel Retailing. Journal of Retailing, 91(2), 174-181. https://doi.org/10.1016/j.jretai.2015.02.005

Venkatesh, V., Thong, J. Y. L., \& Xu, X. (2012). Consumer acceptance and use of information technology: extending the unified theory of acceptance and use of technology, Mis Qaurterly, 36(1), 157178. https://doi.org/10.2307/41410412

Viio, P., \& Grönroos, C. (2016). How buyer-seller relationship orientation affects adaptation of sales processes to the buying process. Industrial Marketing Management, 52, 37-46. https://doi.org/10.1016/j.indmarman.2015.07.013

Viio, P., \& Grönroos, C. (2014). Value-based sales process adaptation: a relationship marketing approach. Industrial Marketing Management, 43(6), 1085-1095. https://doi.org/10.1016/j.indmarman.2014.05.022

Wait, M. (2019). The rivalry between online and direct selling - Is there a winner? Acta Commercii, 19(1), 1-7. https://doi.org/10.4102/ac.v19i1.679

Wang, F., Liu, X., \& Fang, E. (2015). User reviews variance, critic reviews variance, and product sales: an exploration of customer breadth and depth effects. Journal of Retailing, 91(3), 372389. https://doi.org/10.1016/j.jretai.2015.04.007
Wangenheim, F., \& Bayón, T. (2004). Satisfaction, loyalty and word of mouth within the customer base of a utility provider: differences between stayers, switchers and referral switchers. Journal of Consumer Behaviour, 3(3), 211-220. https://doi.org/10.1002/cb.135

Wigand, R. T., Benjamin, R. I., \& Birkland, J. L. H. (2008). Web 2.0 and beyond: Implications for electronic commerce. In ACM International Conference Proceeding Series. https://doi.org/10.1145/1409540.1409550

Wu, H. Y. (2012). Constructing a strategy map for banking institutions with key performance indicators of the balanced scorecard. Evaluation and Program Planning, 35(3), 303-320. https://doi.org/10.1016/j.evalprogplan.2011.11.009

Yadav, M. S., Valck, K., Hennig-Thurau, T., Hoffman, D. L., \& Spann, M. (2013). Social commerce: A contingency framework for assessing marketing potential. Journal of Interactive Marketing, 27(4), 311-323. https://doi.org/10.1016/j.intmar.2013.09.001

Yang, H., \& Feng-Shii Tsai (2007). General E-S-QUAL Scales applied to websites satisfaction and loyalty model. Communications of the IIMA, 7(2), 115126. http://www.iima.org/CIIMA/15CIIMA7-2-07 Yang-Tsai 115-126.pdf

Zuriekat, M., Salameh, R., \& Alrawashdeh, S. (2011). Participation in performance measurement systems and level of satisfaction. International Journal of Business and Social Science, 2(8), 159-169. 